\title{
Correction to: effectiveness of a high- intensive trauma-focused, family-based therapy for youth exposed to family violence: study protocol for a randomized controlled trial
}

Valerie Fictorie ${ }^{2^{*}}$, Caroline Jonkman ${ }^{1,2}$, Margreet Visser ${ }^{1}$, Marjolein Vandenbosch ${ }^{2}$, Majone Steketee ${ }^{3}$ and Carlo Schuenge $\left.\right|^{2}$

Correction to: Jonkman 23:46 (2022)

$$
\text { https://doi.org/10.1186/s13063-021-05981-4 }
$$

Following the publication of the original article [1], we were notified that Valerie Fictorie was mistakenly mentioned as last author instead of first author.

The original article has been corrected.

\section{Author details}

${ }^{1}$ Children's Trauma Centre of Kenter Youthcare, Amsterdam, The Netherlands. ${ }^{2}$ Vrije Universiteit Amsterdam, Amsterdam, The Netherlands. ${ }^{3}$ Verwey-Jonker Institute, Utrecht, The Netherlands.

Published online: 08 February 2022

\section{Reference}

1. Jonkman, et al. Effectiveness of a high-intensive trauma-focused, familybased therapy for youth exposed to family violence: study protocol for a randomized controlled trial. Trials. 2022;23:46. https://doi.org/10.1186/s13 063-021-05981-4.

The original article can be found online at https://doi.org/10.1186/s13063021-05981-4.

* Correspondence: v.fictorie@vu.nl

${ }^{2}$ Vrije Universiteit Amsterdam, Amsterdam, The Netherlands

Full list of author information is available at the end of the article

(c) The Author(s). 2022 Open Access This article is licensed under a Creative Commons Attribution 4.0 International License, which permits use, sharing, adaptation, distribution and reproduction in any medium or format, as long as you give appropriate credit to the original author(s) and the source, provide a link to the Creative Commons licence, and indicate if changes were made. The images or other third party material in this article are included in the article's Creative Commons licence, unless indicated otherwise in a credit line to the material. If material is not included in the article's Creative Commons licence and your intended use is not permitted by statutory regulation or exceeds the permitted use, you will need to obtain permission directly from the copyright holder. To view a copy of this licence, visit http://creativecommons.org/licenses/by/4.0/. The Creative Commons Public Domain Dedication waiver (http://creativecommons.org/publicdomain/zero/1.0/) applies to the data made available in this article, unless otherwise stated in a credit line to the data. 